\title{
The Effect of Competence on Tax Auditor's Performance: The Moderating role of Self-Efficacy and Organizational Commitment
}

\author{
Vince Ratnawati $^{1 *}$, Nita Wahyuni ${ }^{1}$, Rita Anugerah ${ }^{1}$ \\ ${ }^{1}$ Faculty of Economic and Business, Universitas Riau, Pekanbaru, Riau, Indonesia \\ *vincmarbun@yahoo.com
}

\begin{abstract}
Tax revenue is very important because it is the biggest ontributor to Indonesian Budget. Therefore the role of the Directorate General of Taxe is nee 'ed to be able to meet these targets. The aim of this study is to investigate how the omp ency of tax auditors affect tax auditors performance. The study also inves gated the noderating effect of selft efficacy and organization commitment on $t^{t}-r$ ationship between competence on tax auditors performance. A model was developea nnd ested by using a sample of 93 tax auditors from The Directorate General if Taxation in Riau Regional. Data were collected and analyzed by using least squar regression and moderated regression analysis. The result show that competency affect ax auditors performance. The results also indicate that selft efficacy and o sanization commitment strengtenth the effect of competence on tax auditors performance

Keywords: Competence, tax auditors perform nce, self efficacy, organizational commitment
\end{abstract}

\section{Introduction}

Recently the governmer a venue derived from tax revenue plays a very important role in the administration of the state. Th t's because the tax revenue target for the Indonesian Budget is around $87 \%$. Theref ore the government and stakeholders need to pay attention to the order of taxpayers when ca rig out their tax obligations. Good cooperation between tax authorities and taxpayers will be a 10.0 support the achievement of tax revenue targets. The tax authority performs its ole roperly, and is supported by compliant taxpayers in carrying out their tax obligations. 1 taxation system in Indonesia, which uses its own valuation system, allows taxpayers to not ylfill their tax obligations properly

For this reason, it is very necessary for the role of the tax authorities to carry out supervision of taxpayers in fulfilling their tax obligations. In the concept of authority delegation, the party who delegates the authority will of course ensure whether the party delegated with that authority has fulfilled its obligations in accordance with the authority delegated. Therefore the tax authorities need to ascertain whether the taxpayer as the party who is delegated with the authority to calculate the tax itself has implemented it in accordance with applicable regulations.

To ascertain whether the taxpayer has calculated the tax correctly as it should, randomly the tax authorities will conduct an audit of the taxpayer. To be able to explore the potential tax payments from taxpayers, competent tax auditors are needed and have sufficient expertise. Thus, when conducting an audit, the tax auditors can find the potential tax that should be paid by the taxpayer, but has not been paid. Thus the importance of the role of tax auditors to be 